\title{
PHYTOPLANKTON STUDIES IN VETTAR BACKWATERS (COLEROON ESTUARINE COMPLEX) OF THE COASTS OF SOUTHEAST INDIA
}

\section{ESTUDIOS DE FITOPLANCTON EN EL BRAZO DE MAR DEL ESTERO VETTAR (COMPLEJO ESTUARINO COLEROON) EN LA COSTA SURESTE DE LA INDIA:}

\author{
P. Jegadeesan y/and K. Ayakkanne \\ Centre of Advanced Study in Marine Biologs \\ Annamalai Lnitersity \\ Parangipettai. 608502 \\ India
}

JEGADEESAN P. and K. Ayyakkannu. Phytoplankton studies in Vettar hackwaters (Calernon estuarine complex) of the coasts of Southeast India. Estudios de fitoplancton en el brazo de mar del estero Vettar (complejo estuarino Coleroon) en la costa sureste de la India. Ciencias Marinas 12(1):33-49 (I7)

\begin{abstract}
ABSTRAC'T
The river Vettar situated at Lat $11^{\circ} 21^{\prime} \mathrm{N}$ and Long $79^{\circ} 51^{\prime} \mathrm{E}$, one of the back waters of Coleroon estuarine complex was chosen for phytoplankton study. Fortnight samplings were made using No. 30 plank ton net both at high and low tides covering monsoon, postmonsoon and summer periods (October 1982 to June 1983). Analyses were made qualitatively and quantitatively. Totally 81 species belonging to 32 genera were recorded and the seasonal variations of the different species were observed in relation to environmental parameters such as temperature, salinity and dissolved oxygen. Of the total species composition Chaetoceros, Rhizosolenia, Peridinium, Ceratium, Coscinodiscus, Biddulphia, Bacteriastrum and Pleurosigma were represented with $13,9,6,6,5,5,5$, and 4 each respectively. Nitzschia, Navicula, Stephanophyxis and Ditylum were represented with each one species. A maximum number of 359,000 cells/ litre of phytoplankton was recorded in March (Summer) whereas the minimum of 41,500 cells/litre was noticed in December (monsoon). The N:P ratio was ranging from 0.28:1 to 91.53:1. A rich phytoplankton population was found to be associated with low $\mathbf{N}: \mathbf{P}$ ratio whereas a poor population was found to be correlated with high $N$ :P ratio, Species diversity varied from 1.99 to 4.99 (bits/individual) and species richness was recorded between 0.638 and 6.071 and the Evenness was from 0.866 to 1.022 .
\end{abstract}

\section{RESUMEN}

El Rio Vettar, situado a los $11^{\circ} 21^{\prime} \mathrm{N}$ y los $79^{\circ} 51^{\prime} \mathrm{E}$, uno de los brazos del mar del complejo estuarino Vettar, fue utilizado para un estudio de fitoplancton. Se tomaron muestras quincenales usando una red de plancton No. 30 en marea alta y marea baja durante el período del monzón, cn el post-monzón y durante el verano. (Octubre 1982 a junio 1983). Se realizaron análisis cualitativos y cuantitativos. Se obtuvieron un total de 81 especies correspondientes a 32 géneros. Se observaron variaciones estacionales de estas especies en relación con parámetros ambientales como temperatura, salinidad y oxígeno disuelto. Del total de la composición de especies, los géneros Chaetoceros, Rhizosolenia, Peridinium, Ceratium, Cascinodiscus, Biddulphia, Bacteriastrum y Pleurosigma fueron representados por $13,9,6,6,5,5,5$, y 4 especies respectivamente. Nitzschia, Navicula, Stephanophyxis y Ditylum fueron representadas por sólo una especie. Se registró un número máximo de 359,000 células/litro en marzo (verano) y un minimo de 41,500 células/litro en diciembre (monzón). La razón N:P varió de 0.28:1 a 91.53:1. Una población rica de fitoplancton fue asociada con un valor bajo de la razón $N$ :P así como una pobre población fue correlacionada con un valor alto en la razón N:P. La diversidad de especies varió de 1.99 a 4.99 (bits/individuo) y la riqueza de especies obtenida fue entre 0.638 y 6.071 , la equitabilidad fue de 0.966 a 1.022 . 


\section{INTRODUCTION}

In an aquatic environment especially in marine and estuarine situation, photo autotrophic plants are the basis of all life. Several studies have been made on the taxonomy, composition, distribution and ecology of phytoplankton in Vellar and Pitchavaram mangrove waters from Southeast coast of India (Krishnamurthy, 1964; Santhanam et al., 1975; Purushothaman and Bhatnagar, 1976; Ramadhas, 1977; Thangaraj et al., 1979; Venugopalan et al., 1981; Santha Joseph, 1982; Sivakumar, 1982; and Chandran, 1982).

Studies similar to these aspects have also been worked out from the West coast by many investigators (Goswami and Singbal, 1974; Devassy and Bhattathiri, 1974; Pant et al., 1980; Qasim, 1980; and Gajbhiye et al., 1981).

The present study has been carried out in the river Vettar, one of the backwaters of the Coleroon estuarine complex which so far been neglected on the aspects mentioned obove.

\section{DESCRIPTION OF THE STUDY AREA}

The river Vettar, one of the backwaters of the Coleroon estuarine complex, is situated at Pazhayaru (Lat, $11^{\circ} 21^{\prime} \mathrm{N}$; Long $79^{\circ} 50^{\prime} \mathrm{E}$ ) on the Southeast coast of India (Fig. 1). The river Wettar adjoins with Coleroon estuary at a distance of $1 \mathrm{~km}$ from its mouth. The average width and depth of this station is 90 metcrs and 3.5 meters respectively and the total length of the backwater is about 6 $\mathrm{km}$ upstream. The river banks are bordered with mangroves and Paddy fields. Moreover there are two channels joining with the river Vettar, the Sen.mengady channel from the eastern side and the Chinna Vettar from the western side. The drainage from the paddy fields entering into the river Vettar through these two channels. The sampling for the present study were made at the mouth of the river Vettar where it joins with the Coleroon estuary in order to assess the input of phytoplankton through the back waters at low tide and the addition of marine phytoplankton at high tide.

\section{INTRODUCCION}

En un ambiente acuático, especialmente en condiciones marinas o estuarinas, los vegetales fotoautotróficos son la base de toda la vida. Se han realizado muchos estudios en la taxonomía, composición, distribución y ecología del fitoplancton en los man. glares del Vellar y Pitchavaram, en la costa sureste de la India (Krishnamurthy, 1964; Santhanam et al., 1975; Purushothaman y Bhatnagar, 1976; Ramadhas, 1977; Thangaraj et al., 1979; Benugopalan et al., 1981; Santha Joseph, 1982; Sivakumar, 1982 y Chandran, 1982).

Varios investigadores han realizado estudios similares en la costa oeste (Goswami y Singbal, 1974; Devassy y Bhattathiri, 1974; Pant et al., 1980; Qasim, 1980 y Gajbhite et al., 1981).

El presente estudio fue realizado en el Río Vettar, uno de los brazos del mar del complejo estuarino Coleroon, que había sido ignorado en los aspectos antes mencionados.

\section{DESCRIPCION DEL AREA DE ESTUDIO}

El Río Vettar, uno de los brazos de mar del complejo estuarino Coleroon, está localizado en Pazhayaru $\left(11=21^{\prime} \mathrm{N}\right.$; $\left.79=50^{\prime} \mathrm{E}\right)$ en la costa suroriental de la India. (Fig. 1).

El Río Vettar se incorpora al estero Coleroon a $1 \mathrm{~km}$ de la boca del estero. El promedio de anchura y profundidad de esa localidad es de $90 \mathrm{~m}$ y $3.5 \mathrm{~m}$, respectivamente y la longitud total del brazo de mar es de aproximadamente $6 \mathrm{~km}$. Los bordes del río están rodeados por manglares $\mathrm{y}$ arrozales. Además, existen dos canales que se juntan en el Río Vettar, que son; el canal Semmengadu, proveniente del lado este, y el Chinna Vettar, del lado oeste. El drenaje de los arrozales se vierte en el Río Vettar a través de estos dos canales.

Las muestras del presente estudio fueron tomadas en la boca del Río Vgttar, en donde se junta con el estero Coleroon, con la intención de obtener el fitoplancton que 


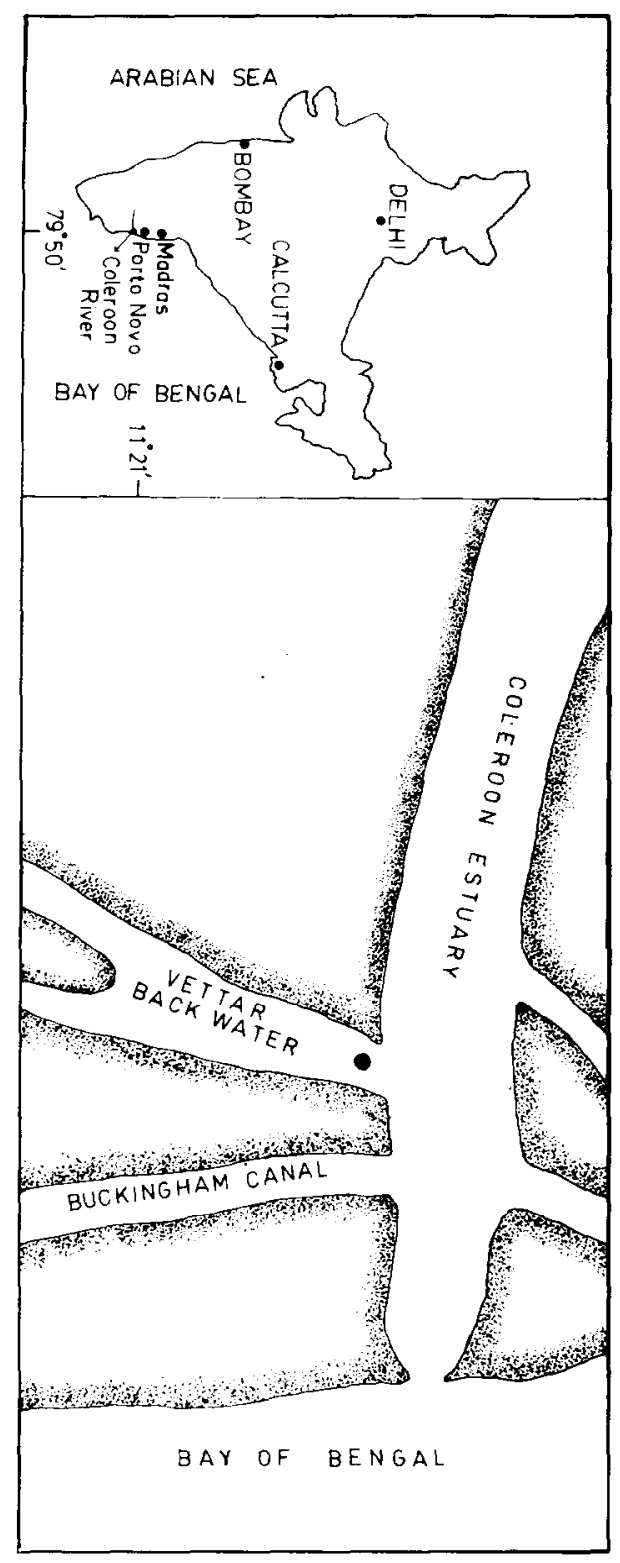

Fig. 1. Location of sampling site. Incalización del área de muestreo

\section{MATERIALS AND METHODS}

Temperature was measured using a sensitive celsius thermometer of $0.5^{\circ} \mathrm{C}$ accuracy. Salinity was estimated Harvey's direct method by silver nitrate titration method using penetra a través del brazo de mar en marea baja y la adición de fitoplancton en marea alta.

\section{MATERIALES Y METODOS}

La temperatura se midió usando un termómetro en grados Celsius con resolución de $0.5=$ C. La salinidad fue estimada con el método directo de Harvey con nitrato de plata usando cromato de potasio como indicador. La concentración de oxígeno disuelto fue estimada mediante el método de Wink. ler y el fósforo reactivo disuelto y los nitratos fueron estimados por el método calorimétrico descrito por Strick land y Parsons (1972).

El fitoplancton colectado para estudio cualitativo, se obtuvo empleando una red de plancton No. 30 (apertura de malla $48 \mathrm{~m} / \mathrm{u}$ ).

Para estudio cuantitativo del fitoplancton, fue colectada agua superficial usando una cubeta de plástico limpia y transfiriendo el agua a una botella de polietileno con algunas gotas de formol neutralizado al $5 \%$ como preservador. El fitoplancton fue observado después de 24 horas mediante un microscopio invertido para plancton Utermohl.

La diversidad de especies fue determinada usando el índice de Shannon (Pielou, 1975) y la riqueza de especies (SR) fué calculada con la expresión de Gleason (1922). La equitabilidad ( $\mathrm{J}$ ') fue calculada usando la fórmula de Pielou (1966).

\section{RESULTADOS}

\section{Hidrografía}

La Fig. 2 muestra los datos de temperatura, salinidad y oxígeno disuelto, obtenidos durante el presente estudio. El rango de temperatura en marea alta fué de $25.0=\mathrm{C}$ a $29.0=C$ y en marea baja de $25.0=C$ a $31.0=C$. Los valores más bajos fueron obtenidos durante el monzón (diciembre) y los valores más altos durante el verano (mayo). En general la temperatura durante marea alta fue inferior a la temperatura durante marea baja porque muchos de los muestreos fueron realizados durante las horas de la mañana (al 

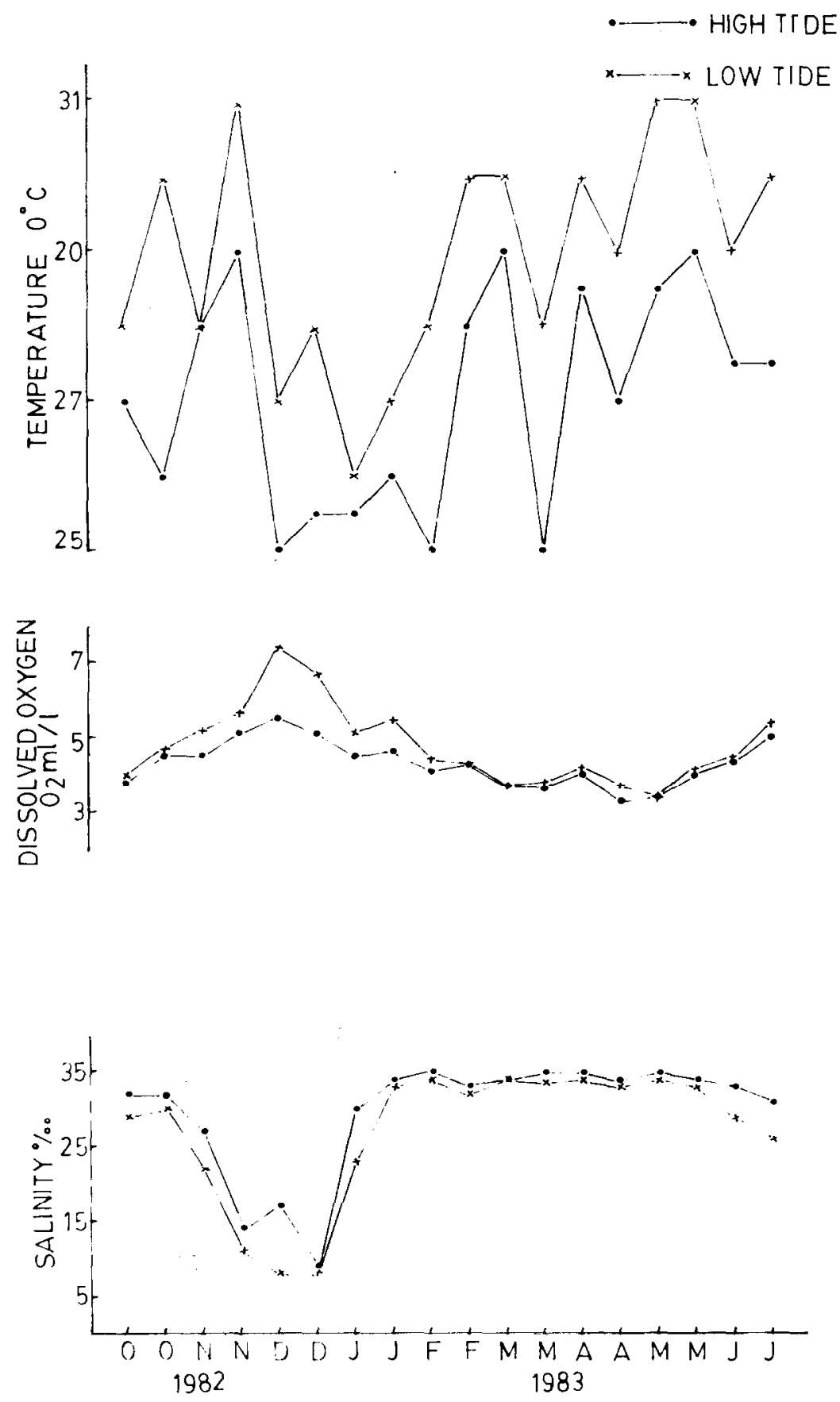

Fig. 2. Tidal variations in temperature, salinity and dissolved oxygen.

Variacién de la marea, de la temperatura, salinielad y ovigeno disuctlo. 
potassium chromate as indicator. The dissolved oxygen concentration was estimated by the Winkler's method and the dissolved reactive phosphorus and nitrate were estimated by colorimetric method as described by Sirickland and Parsons (1972).

Phytoplankton was collected using No. 30 plankton net (bolting silk mesh aperture size $48 \mathrm{~m} / \mathrm{u}$ ) for qualitative study. For quantitative study, the surface water sample was collected using a clean plastic bucket and transferred to 1 litre poly thene bottle with a few drops of $5 \%$ neutralised dormalin as preservative. The phytoplankton was observed under Utermohl's inverted plankton Microscope after 24 hours.

The species diversity was determined using Shannon's formula (Pielou, 1975) and species richness ( $\mathrm{SR}$ ) was calculated by Gleason's (1922) formula. Evenness (J') was calculated by using the formula of Pielou, (1966).

\section{RESLLTS}

\section{Hydrography}

The data obtained for temperature, salinity and dissolved oxygen at high tide and low tide during the present study are give in Fig. 2. The surface water temperature at high tide ranged from $25.0^{\circ} \mathrm{C}$ to $29.0^{\circ} \mathrm{C}$ and at low tide it varied between $26.0^{\circ} \mathrm{C}$ and $31.0^{\circ} \mathrm{C}$. Low values were observed in monsoon (December) and higher values were recorded in summer (May). In general, the high tide temperature was lower than that of the low tide temperature, because most of the collections were done in the morning hours (around 7.30 A.M.). At high tide, the salinity waried between $9.09 \%$ oo. and $35.35 \%$ oo. and it ranged from $7.57 \%$ oo. to $34.34 \%$ oo. at low tide.

Dissolved oxygen recorded at high tide was ranging between $3.27 \mathrm{ml} / 1$ and $5.53 \mathrm{ml} / 1$ whereas at low tide from 3.28 to $7.35 \mathrm{ml} / 1$. The minimum was recorded in summer and the maximum was found to occur in monsoon period at both tides. A slight increase in the dissolved exygen content in June was may be due to the addition of fresh water from the adjacent paddy fields. rededor de las 7:30 a.m.). En marea alta, la salinidad varió de $9.09 \%$ oo y su rango fue de $7.57 \%$ oo a $34.34^{\circ} /$ oo en marea baja.

El oxígeno disuelto medido en marea alta osciló entre $3.27 \mathrm{ml} / 1$ y $5.53 \mathrm{ml} / \mathrm{l}$ mientras que en marea baja fue de $3.28 \mathrm{ml} / \mathrm{l}$ a 7.53 $\mathrm{ml} / \mathrm{l}$. El mínimo se midió en verano y el máximo ocurrió durante el monzón, en ambas mareas. Un ligero incremento en el oxígeno disuelto en junio fue probablemente producto del aporte de agua dulce de los arrozales adyacentes.

\section{Razón N:P}

En la figura 3 se muestran las variaciones en la razón N:P (nitratos: fosfatos). El rango de variación de esta razón fue de $2.76: 1$ a 72.12:1 en marea alta y de 0.28:1 a 91.53:1 en marea baja.

Los valores mínimos y máximos de la razón $N$ :P fueron obtenidos en verano $y$ durante el monzón, respectivamente. Se observó un máximo en la razón $\mathrm{N}: \mathrm{P}$, durante marea alta, en el post-monzón temprano (enero), que fué notado también durante el monzón (diciembre) en marea baja. Los valores mínimos fueron medidos en ambas mareas durante el verano (abril).

\section{Plancton}

Un total de 81 especies de fitoplancton comprendiendo 65 especies de diatomeas, 13 especies de dinoflagelados y 3 especies de clorofitas, fueron observadas durante el presente estudio ('Tabla $I$ ).

Del total de especies del fitoplancton correspondió $88.24 \%$ a las diatomeas, $9.49 \%$ a los dinoflagelados y $2.27 \%$ a las clorofitas.

Entre las diatomeas, las especies dominantes obtenidas fueron: Chaetoceros lorenzianus, C. laciniosum, C. boreale, Biddulphia sinensis, Coscinodiscus Ocular iridis, C. centralis, C. gigas, Nitzschia seriata, $N$. clostrium, Rhizosolenia alata, R. imbricata, R. stoltherfothii, Stephanophyxis turris, Thallasiothrix frauenfeldii y Thallassiothrix nitzschioides. 

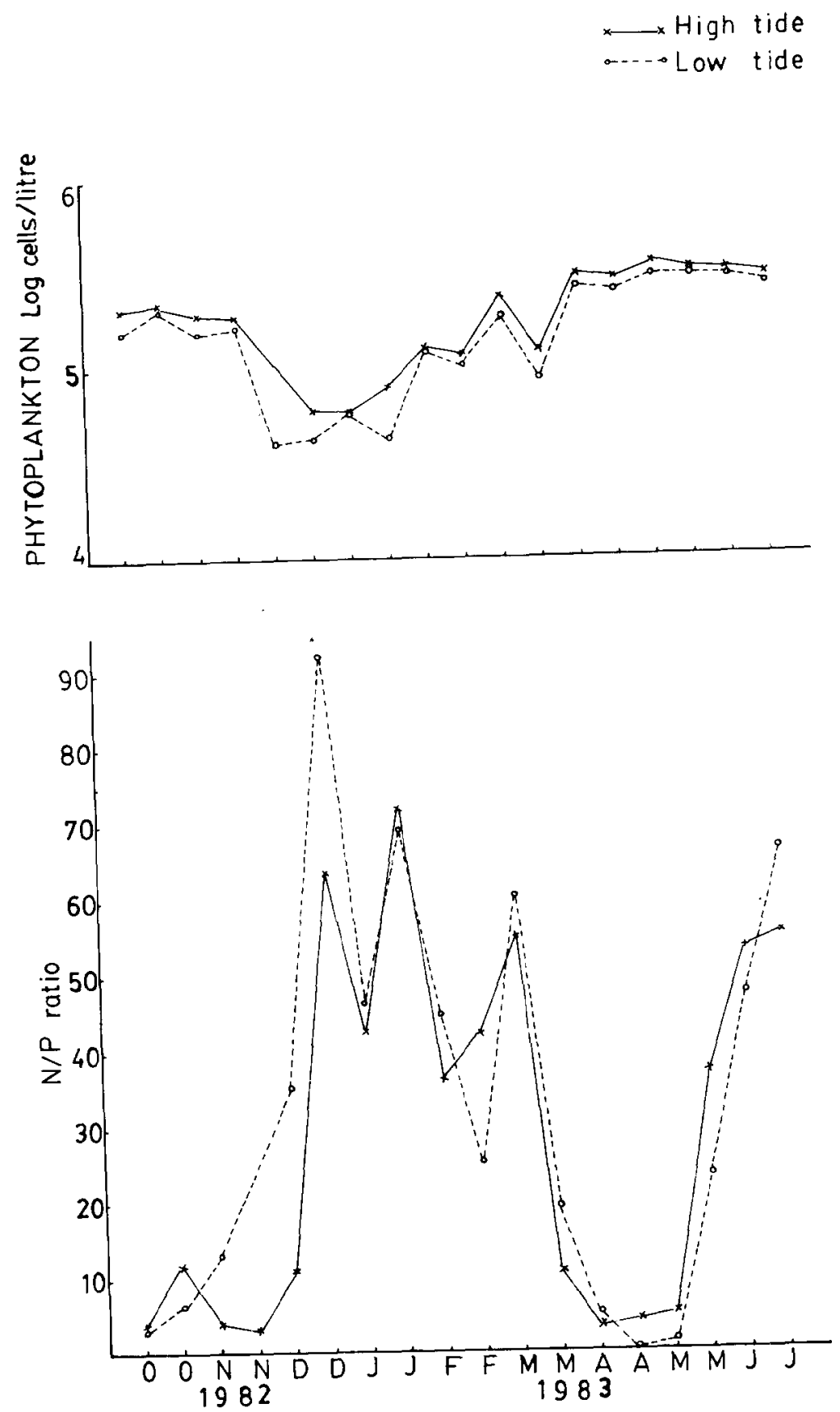

Fig. 3. Tidal variations of phytoplankton density and M:P ratio.

Variación en la marea, de la densidad del fitoplancton? la razón N:P. 


\section{N:P ratio}

Variations in the N:P (Nitrate and Phosphate) ratios are shown in Fig. 3. The ratios were fluctuating from $2.76: 1$ to $72.12: 1$ at high tide and between 0.28:1 and 91.53:1 at low tide. The minimum and maximum values of $N: P$ ratio were found in summer and monsoon periods respectively. At high tide, the peak in $N: P$ ratio was observed in early postrmonsoon (January) whereas it was noticed in monsoon (December) at low tide. The lowest values were recorded at both tides during summer (April).

\section{Plankion}

A total number of 81 species of phytoplankton comprisirs 65 species of diatoms. 13 species of dinoflagellates and 3 species of chlorophyceae were recorded in the present study (Table. I). Among the total phytoplankton diatoms, dinoflagellates and chlorophyceae were constituted $88.24 \%$ oo, $9.49 \%$ oo and $2.27 \%$ respectively.

Chaetoceros lorenzianus, C. laciniosum, C. boreale, Biddulphia sinensis. Coscinodiscus, Ocular iridis, C. centrali, C. gigas. Nitzschia seriate, $N$. clostrium, Rhizosolenia alata, $R$. imbricata, $R$. stoltherfothii. Stephanophyxis turris, Thallassiothrix frauenfeldii and Thallassionema nitzschioides were found to be the dominant species among the diatoms.

Among the dinoflagellates Ceratium fusus. C. macroceros and Peridinium depressum were found to be the common forms.

The freshwater species such as Pediastrum clathratum, Spirogyra sp. and Volvox sp. were also recorded during monsoon period.

Species diversity $\left(\mathrm{H}^{\prime}\right)$ were ranging from 2.55 to $4.99 \mathrm{bits} /$ individual, at high tide and 1.99 to $4.80 \mathrm{bits} /$ individual, at low tide (Fig. 4) A high diversity value was found to be associated with summer months and the low diversity values was in monsoon months. It was also noticed that the diversity values were higher at high tide than at low tides.
Entre los dinoflagelados, Ceratium fusus, C. macroceros y Peridinium depressum fueron los más comunes.

Las especies de agua dulce, como Pediastrum clathratum, Spirogyra sp. y Volvox sp. fueron también identificados durante el período del monzón.

La diversidad de especies (H') osciló entre 2.55 y $4.99 \mathrm{bits} /$ individuo durante marea alta, y de 1.99 a 4.80 bits/ individuo durante marea baja. (Fig. 4). El valor alto de diversidad fue asociado con los meses de verano y los valores mínimos ocurrieron en los meses de monzón. Se notó también que los valores de diversidad fueron más altos durante marea alta que durante marea baja.

La riqueza de especies (SR) varió entre 1.04 y 6.07 en marea alta y 0.64 a 5.34 en marea baja.

Los valores más bajos fueron obtenidos durante el monzón tardío y el post-monzón temprano. Los valores mayores fueron obtenidos durante el verano entre marea alta y marea baja. La equitabilidad varió entre 0.88-0.97 durante marea alta y 0.87-1.02 durante marea baja.

\section{Densidad de población}

Un análisis cuantitativo del fitoplancton, realizado en el presente estudio, mostró grandes fluctuaciones entre marea alta y baja. En marea alta, la densidad de población varió de $0.45 \times 10^{5} \mathrm{cel} / 1$ a $3.59 \times 10^{5} \mathrm{cel} / 1$ y en marea baja de $0.41 \times 10^{5} \mathrm{cel} / 1$ a $3.12 \times 10^{2}$ cel/1 (Fig. 3).

Los máximos valores del fitoplancton fueron observados durante el verano y durante el periodo premonzón. El flujo de agua dulce del monzón se traduce en una baja densidad del fitoplancton durante diciembre y aumenta gradualmente hasta alcanzar su máxio durante mayo (verano). Posteriormente, en el mes de junio, la densidad de fitoplancton desciende debido a un aumento del flujo de agua dulce al brazo de mar, procedente de los canales de irrigación. 

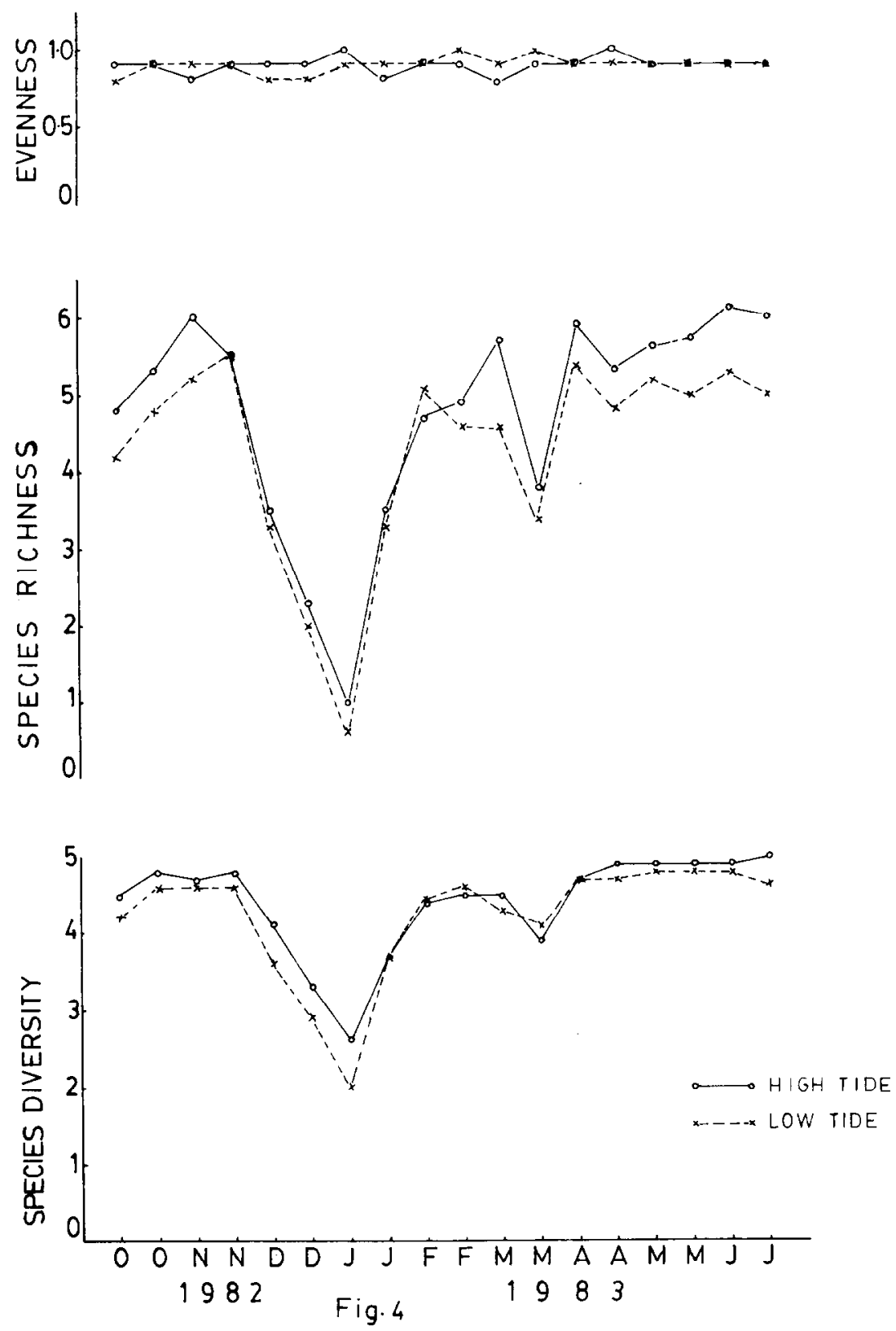

Fig. 4. Tidal variations in species diversity, species richness and evenness of phy toplankton.

Variación en la marea, de la densidad de especies, riqueza de especies y equitabilidad del fitoplancton. 
Species richness (SR) was found to vary between 1.04 and 6.07 at high tide. At low tide, it ranged from 0.64 to 5.34. Lower values were recorded during late monsoon and early postmonsoon periods. The higher values were noticed during summer.

Evenness was not showing any significant difference between high tide and low tides. Evenness varied between 0.88 and 0.97 during high tide and 0.87 and 1.02 at low tide.

\section{Population density}

Quantitative study of phytoplanktoon made in the present study showed a great fluctuations between high tide and low tide. At high tide, the population density varied from $0.45 \times 10^{5}$ cells/litre to $3.59 \times 10^{5}$ cells litre and at low tide, it was recorded between $0.4 \times 10^{5}$ cells/litre and $3.12 \times 10^{5}$ cells/litre (Fig. 3).

The maximum values of phytoplankton were observed during summer and premonsoon periods. Monsoonal freshwater flow resulted to a lower density of phytoplankton during December and it was gradually built up and reached its maximum during May (summer). But again in the month of June the phy toplankton density was poor due to a high amount of freswater inflow into the backwater from the irrigation channels. In general, the quantum of phytoplankton was more in numbers at high tide.

\section{DISCLSSIOY}

\section{Phyloplankton and temperature}

Ramadhas (1977) reported that the phy. toplankton count was found to be at maximum when the temperature of the water was about $29^{\circ} \mathrm{C}$. In the present study, the peak in phytoplankton was also observed when the temperature was $28.5^{\circ} \mathrm{C}$. The maximum temperature of both high $\left(28.5^{\circ} \mathrm{C}\right)$ and low tides $\left(31.0^{\circ} \mathrm{C}\right)$ were recorded during summer (May) with maximum number of Phytoplankton population density of $3.59 \times 10^{5}$ cells/litre at high tide and $3.12 \times 10^{5} \mathrm{cells} /$ litre at low tide. Studies similar to this was noticed by Chandran (1982) who recorded that at the maxi-
En general la cantidad de fitoplancton es mayor en número durante marea alta que durante marea baja.

\section{Discusión}

Ramadhas (1977) reporta que el fitoplancton será máximo cuando la temperatura del agua sea de alrededor de $29^{\circ} \mathrm{C}$. En el presente trabajo se observó el máximo en el fitoplancton cuando la temperatura del agua fue de $28.5^{\circ} \mathrm{C}$. La máxima temperatura del agua en marea alta $\left(25.5^{\circ} \mathrm{C}\right)$ y en marea baja $\left(31.0^{\circ} \mathrm{C}\right.$ ) fue medida durante el verano (mayo) con un número máximo de densidad de población del fitoplancton de $3.59 \times 10^{5} \mathrm{cel} / 1$ en marea alta y $3.12 \times 10^{5} \mathrm{cel} / 1$ en marea baja. En estudios similares a éste, realizados por Chandran (1982), se ha reportado que a la temperatura máxima de $33.5^{\circ} \mathrm{C}$ la densidad del fitoplancton fue de $13.8 \times 10^{5} \mathrm{cel} / 1 \mathrm{du}$ rante el verano en el estero de Vellar. La asociación entre máxima temperatura y máxima densidad observada del plancton, obtenida en el presente estudio, está de acuerdo con anteriores reportes de Santhanam (1976), Sundararaj, (1978) y Thangaraj et. al. (1979) para aguas de Portonovo.

Se registraron bajas temperaturas en ambas mareas durante el monzón y el postmonzón, siendo de $25^{\circ} \mathrm{C}$ y $16^{\circ} \mathrm{C}$ respectivamente. Consecuentemente se obtuvieron bajas densidades de fitoplancton durante el período del monzón $\left(0.45 \times 10^{5} \mathrm{cel} / 1\right)$ en marea alta, y de $0.41 \times 10^{5} \mathrm{cel} / 1$ en marea baja. Lo anterior está de acuerdo con Chandran (1982), quien observó que un mínimo de temperatura de $24.0^{\circ} \mathrm{C}$ es seguido por un mínimo de densidad de población del fitoplancton de $0.22 \mathrm{X10}^{2} \mathrm{cel} / 1$ durante el mon. zón. Sivakumar (1982) es de la opinión, de acuerdo con sus estudios, que bajas temperatu. ras con bajas densidades de fitoplancton obedecen a flujos de agua dulce en el brazo de mar y no es debido a baja temperatura.

Del presente estudio se sugiere que la baja densidad de población del fitoplaneton no es debida únicamente a baja temperatura del agua sino también por el aporte de agua dulce. 
mum temperature of $33.5^{\circ} \mathrm{C}$ the phytoplank. toil was $13.85 \times 10^{5}$ cells/litre during summer in Vellar estuary. A high temperature associated with maximum plankton density obsewed in the present study was in confirmity with the earlier reports of Santhanam (1976), Suntararai (1978) and Thangaraj et al. (1979) from Portonovo waters.

Lon temperatures were noticed at both high and low tides during monsoon and postmonsoon seasons $25^{\circ} \mathrm{C}$ and $26^{\circ} \mathrm{C}$ respeclively. Consequently low densities of phytoplall hlon were observed during monsoon period $0.45 \times 10^{5}$ ceells/litre at high tide and 0.11 、 $10^{5}$ cells/litre at low tide. This was in confirmity with Chandran (1982), who observed that a minimum temperature of $24.0^{\circ} \mathrm{C}$ followed by minimum population density of $0.22 \times 10^{2}$ cells/litre during monsoon. Sivahumar (1982) was of opinion from his studies that low temperature with low phytoplankton density was chiefly due to freshwater flow into the backwater and not due to low temperature. However, from the present study it is suggested that the low phytoplankton population density is not only due to the low temperature but also with freshwater flow.

The correlation coefficient analysis between temperature and phytoplankton showed a highly significant positive correlation at $5 \%$ level both at high and low tides. The density of phytoplankton is directly proportional to temperature and vice versa. (H.T $r$ $=0.7271$ P 5\%; L.T r $=0.8423$ P 5\%). (Table II).
El análisis de coeficiente de correlación entre temperatura y fitoplancton muestra una correlación positiva significante a un nivel de $5 \%$, en ambas mareas. La densidad del fitoplancton es directamente proporcional a la temperatura y viceversa. (M.A. $r=$ 0.7271 P 5\%; M.B. $r=0.8423$ P 5\%) (Tabla II).

\section{Fitoplancton y salinidad}

El patrón estacional de la salinidad observada en el presente estudio muestra valores bajos durante el monzón y valores altos durante el verano.: Se observa un decrecimiento en la salinidad a partir del período del monzón, la cual lentamente se incrementa en el postmonzón, alcanzando su valor máximo en verano. Se detecta un estado de salinidad estable en el estero Coleroon durante el verano. Observaciones similares a estas fueron realizadas por Ramadhas (1977) y Sivakumar (1982) en sus trabajos sobre el estero Vellar.

En el presente estudio, la salinidad mostró su máximo valor de $35.35 \%$ oo durante el verano (mayo) con la máxima densidad del fitoplancton de $3.59 \times 10^{5} \mathrm{cel} / 1$ y su mínimo valor de $9 . \%$ oo fue medido cuando la densidad del fitoplancton fue de $0.45 \times 10^{5}$ cel/l. En marca baja, el valor de salinidad osciló entre $7.57 \%$ oo (monzón) y $34.34 \%$ (verano).

Se asociaron altos valores de salinidad con la población del fitoplancton, en ambas mareas y durante el verano. Krishnamurthy et al. (1979) notaron una correlación directa

TABLE II.Simple correlation coefficient ' $r$ ' between phytoplankton density and evironmental parameters (log. transformed).

TABLA II.Coeficiente de mrrelación simple 'r' entre densidad del fitoplancton y parámetros ambientales. (Transformada log.).

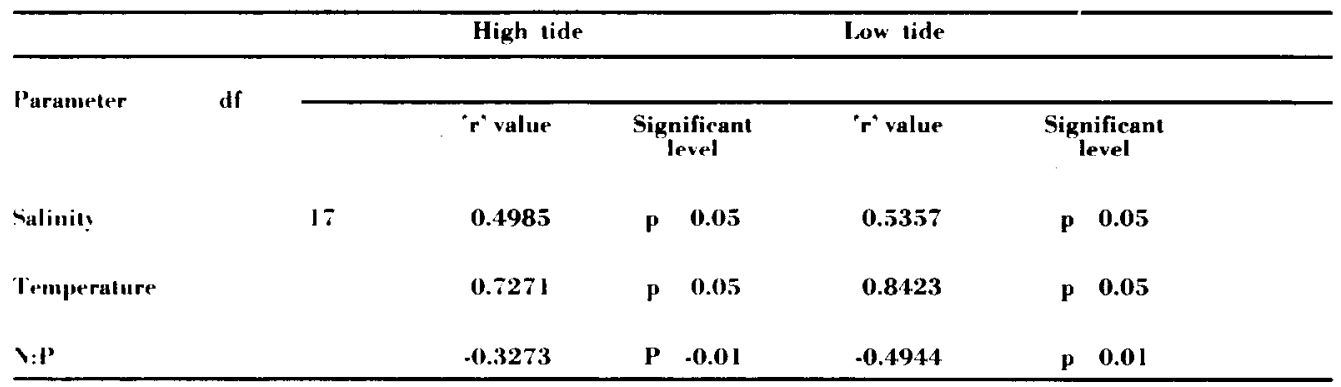


Phytoplankton and salinity

The seasonal pattern of salinity observed in the present study showed low values during monsoon and high values during summer. A decrease in salinity was noticed from the monsoon period which which slowly being built up in postmonsoon reaching its maximum in summer. A steady state of salinity level in Coleroon estuary was found to occur in summer. Study similar to these observations were made by Ramadhas (1977) and Sivakumar (1982) in their studies from Vellar estuary.

In the present study, salinity showed its maximum value of $35.35 \%$ oo. during summer (May) with the maximum phytoplankton density of $3.59 \times 10^{5}$ cells/litre and low salinity of $9.0 \%$ oo. was recorded when the Phytoplankton density was $0.45 \times 10^{5}$ cells/ litre. At low tide. the salinity value was recorded between $7.57 \%$ oo. (Monsoon) and $34.34 \%$ oo (Summer).

High values of salinity both at high and low tides were associated with the phytoplankton population during summer. Krishnamurthy et al. (1979) noticed such direct correlation between high salinity $(34.2 \%$ oo $)$ and the high plankton density in summer (April). Smayda (1965) recorded that when the salinity was high phytoplankton population was also in high density. Probably these organisms were of typically marine nature. Santhakumari (1971) had also made such maximum salinity $(31.24 \mathrm{O} / \mathrm{oo}$.) with the maximum phytoplank ton count $(49290$ cells $/ 10$ $\mathrm{ml)}$ observations in during summer (May) and the low values $(3.20 \%$ oo $)$ was found to be associated with low density of phytoplankton ( 1530 cells $/ 10 \mathrm{ml}$ ) in monsoon (November) from the Vellar estuary. Krishnamurthy (1967) had also noticed that phytoplank ton peak was occuring in the months of May and July. This obvservation is in confirmity with that of Sivakumar (1982) who noticed from the tidal zone of Vellar estuary. In the present study diatoms ranks first $(88.24 \%$ oo) followed by dinoflagellates $(9.49$ $0 / 00)$ and chlorophyceae $(2.27 \%$ oo) (LaraLara et al., 1980). In Long Island estuary Bruno et al. (1981) have also found such the entre alta salinidad $(34.2 \%$ oo) y alta densidad de plancton en verano (abril). Smayda (1965) encontró que cuando la salinidad es alta, la densidad de población del fitoplancton es también alta. Probablemente estos organismos sean de naturaleza típicamente marina. Santhakumari (1971) ha relacionado también el máximo de salinidad (31.24\% \%o) con el máximo número del fitoplancton $(49.290 \mathrm{cel} / 10 \mathrm{ml})$ observados durante el verano (mayo) y los valores menores (3.20 $\%$ oo) fueron asociados a una densidad de fitoplancton de $(1530 \mathrm{cel} / 10 \mathrm{ml})$ en el monzón (noviembre) en el estero Vellar. Krishnamurthy (1967) ha notado también que el máximo de fitoplancton ocurre durante los meses de mayo y junio. Esta observación coincide con la de Sivakumar (1982), en la zona de mareas del estero Vellar. En el presente trabajo las diatomeas ocupan el primer plano (88.24\%), seguidas por los dinoflagelados $(\mathbf{9 . 4 9 \%})$ y clorofitas $(2.27 \%)$ (Lara-Lara et al., 1980). En el estero de Long Island, Bruno et al. (1981) han obtenido también la misma secuencia en la presencia del fitoplaneton.

Se encontró una correlación positiva con nivel de $5 \%$ entre la salinidad y el fitoplancton en marea alta y baja. Esto puede ser explicado en función de que los valores fueron obtenidos durante el verano, cuando no existen grandes fluctuaciones de salinidad en el estero. Sin embargo, todo el estero está influenciado por aguas neríticas en marea alta, lo cual añade una población adicional de fitoplancton marino (marea alta $\mathbf{r}=$ $0.49852 ; \mathrm{P} 5 \%$; marea baja $r=0.5357$;P 5\%) (Tabla III).

\section{Fitoplancton y oxígeno disuelto}

El contenido de oxígeno disuelto fue alto durante el monzón, cuando el estero tiene la total influencia del agua de lluvia. Se registraron bajos valores del fitoplancton durante este período. Pero en verano las condiciones son diferentes, es decir que (i.e) altos valores de fitoplancton coinciden con bajos valores de oxígeno disuelto y entonces son inversamente proporcionales. Esto resulta de acuerdo con lo expuesto por Qasim y Gopinathan (1969) del brazo de mar Cochin; Vijayalakshmi y Venugopalan (1973) y Thangaraj et al. (1979) del estero Vellar. 

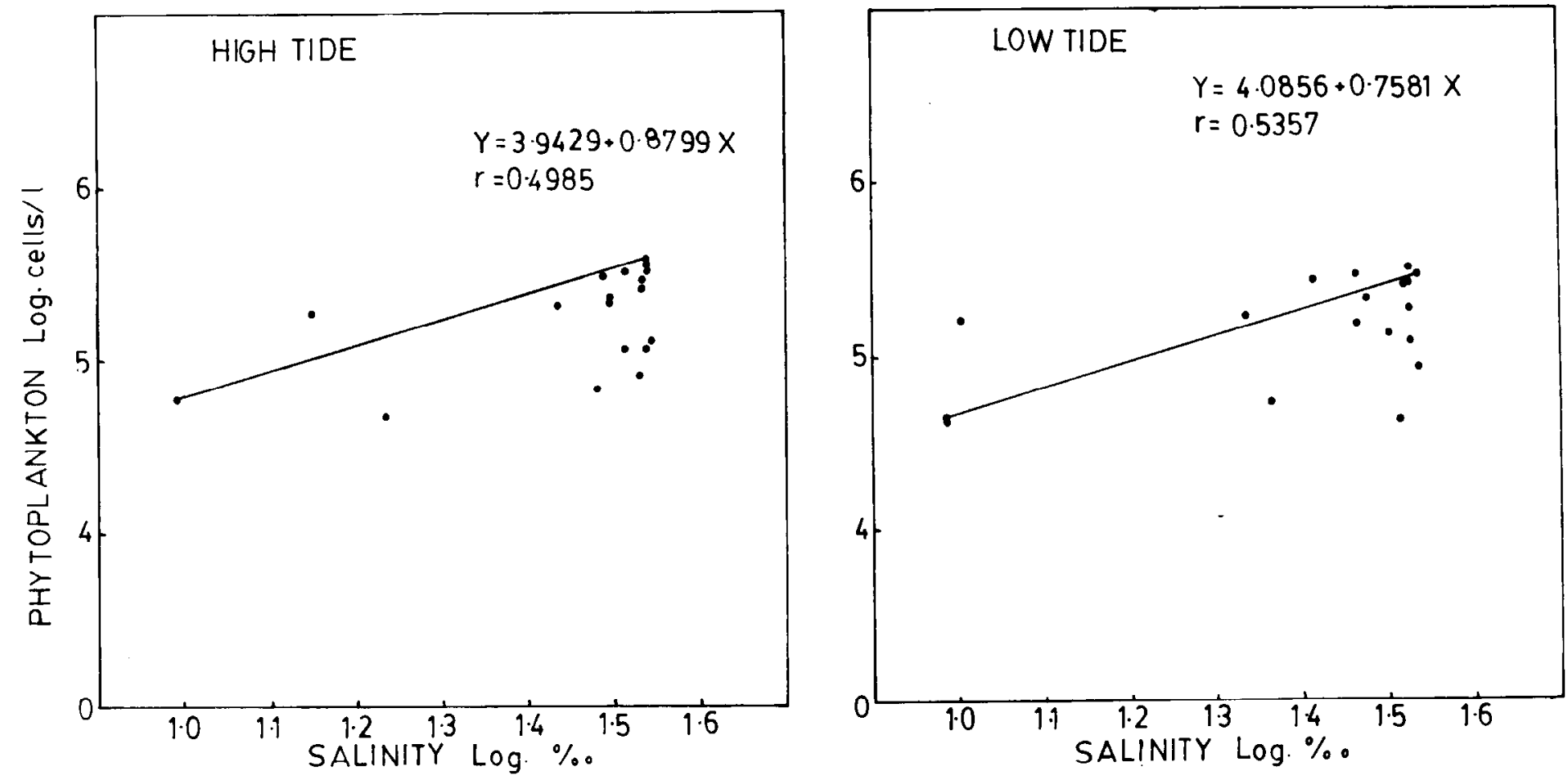

Fig. 5. Relationship between phytoplankton and salinity. Relación entre fitoplancton y salinidad. 
T'ABLE IISimple correlation coefficient ' $r$ ' between phytoplankton density and environmental parameters (log. trans-formed).

TABLA II Coeficiente de correlación simple ' $r$ ' entre densidad del fitoplancton y parámetros ambientales. (Transformada log.)

\section{DIATOMS}

\author{
Bacillaria paradoxa \\ Bacteriastrum cosmosum \\ B. delicatulum \\ B. elongatum \\ B. hyalinum \\ B. varians \\ Bellerochea malleus \\ Biddulphia aurito \\ B. regia \\ B. mobiliensis \\ b. rhombus \\ B. sinensis \\ Chaetoceros atlanticum \\ C. boreale \\ C. cortstrictum \\ C. convolutum \\ C. curvisetum
}

\section{DINOPHYCEAE}

Ceratium bucephalum

C. furca

C. Jusus

C. macroceros

C. trichoceros

C. tripos

Dinophysis caudata
C. decipiens

C. diadema

C. didymum

C. diversum

C. laciniosum

C. lorenzianum

C. peruvianum

C. socialis

Corethron criophilum

Coscinodiscus centralis

C. gigas

C. lineatum

C. marginatus

C. ocular iridis

Detonula schroder

Ditvlum brightwelli

D. sol
Eucambia zodiacus
Gyrosigma balticum
Hemidiscus hardimanianus
Lauderia boreale
Melosira sulcata
Navicula cancellata
N. marina
Nitzchia clostrium
N. seriata
Planktoneilla sol
Pleurosigma aestuarii
P. directum
p. elongatum
P. normanii

Rhizosolenia alata

R. calcar avis

R. cylindrus

$R$. hebetata

R. imbricata

$R$. setigera

R. shrubsolii

R. stoltherfothii

R. styliformis

Skeletonema costatum

Stephanopyxis palmariana

S. turris

Synedra formosa

Thalossiothrix frauenfeldii

Thalassionema nitzschioides

Thalassiosira subtilis

Peridinium conicum
P. curtipes
P. depressum
P. divergens
P. oceanicum
P. oblongum
CHLOROPHYCEE
Pediastrum clathratum
Spirogyra sp.
Volvox sp.

similar trend in occurrence of phytoplankton.

A significant positive correlation (Fig. 5) at 5\% level was found to exist between the salinity and phytoplankton densities at high tide and low tide. This may be explained that the high sallinity was recorded during summer wherenot much fluctuations in salinity in the estuary. Further, the entire estuary was influenced by the neritic waters at high tide which enhance the additional phytoplankton population from the sea (High tide $r=.49852 \mathrm{P} 5 \%$; Low tide $\mathrm{r}=0.5357 \mathrm{P}$ 5\%). (Table III).

\section{Phytoplankton and dissolved oxygen}

The dissolved oxygen content was found to be high in monsoon when the estuary was at the full influence of monsoonal rainwater and low numbers of phytoplankton was different i.e. high numbers of phytoplankton were recorded while the dissolved oxygen
En el presente estudio se encuentra un valor alto de densidad del fitoplancton y un mínimo de oxígeno disuel to durante el verano. Esto puede obedecer a la alta temperatura y salinidad del agua. Lo anterior está de acuerdo con Fehadray y Bhargava (1972), quienes realizaron observaciones en los esteros Mandovi y Zuari; así como con Goa y Rejendran (1974) en el estero Vellar.

Ramadhas (1977) y Sivakumar (1982) reportan que una alta actividad fotosintética con alta densidad de población de fitoplancton resulta en una mayor concentración del oxígeno disuelto, durante el verano, en el estero Vellar. Por el contrario, en el brazo de mar de Vettar, se obtiene una concentración baja de oxígno disuelto durante el verano.

A finales del verano, (junio), cuando la densidad del fitoplancton se encuentra estable, se nota un ligero aumento en la concentración de oxígeno disuelto, misma que puede ser debido al aporte de agua dulce de los canales de irrigación.

\section{Fitoplancton y la razón N:P}

La razón N:P en el presente estudio mostró un valor bajo de 0.28: 1 en verano (mayo) con densidad de fitoplancton alta; y un valor alto de 91.53:1 durante el monzón 
content was low and thus it was inversely proportional. This is in agreement with the findings of Qasim and Gopinathan (1969) from Cochin backwaters; Vijayalakshmi and Vanugopalan (1973) and Thangaraj et al. (1979) from the Vellar estuary.

In the present study though a high phytoplankton density was observed but a low dissolved oxygen content was recorded in summer. This may be explained that due to high temperature and salinity of the water. This is in agreement with Dehadrai and Bhargava (1972) who made observations in Mandovi and Zuari estuaries of Goa and Rajendra (1974) in the Vellar estuary.

Ramadhas (1977) and Sivakumar (1982) reported that the high photosynthetic activity with high density of phytoplankton resulted in high dissolved oxygen concentration during summer in the Vellar estuary. On the contrary in Vettar backwater a low oxygen concentration was recorded in summer.

In late summer (Jure) when the phytoplankton number was in stready state, a light increase in dissolved oxygen concentration was noticed which may be due to freshwater inflow from the irrigation chennels.

\section{Phytoplankton and N:P Ratio}

The N:P ratio in the present study showed a low value of 0.28:1 in summer (May) with high phytoplankton density and a high value of 91.53:1 in monsoon (December) with low density of phytoplankton. Similar trend in the $N: P$ ratios were recorded by many investigators. In Vellar estuary Rajendran (1974) recorded between $0.2: 1$ and 85.2:1 during summer and monsoon periods respectively. Ramadhas (1977) recorded from a low value of 1.5:1 during summer to a high value of $32: 1$ in monsoon period in the mouth of Vellar estuary. In the tidal zone of Vellar estuary Sivakumar (1982) noted the $\mathrm{N}: \mathrm{P}$ ratio from 0.02:1 (Summer) to 170.2:1 (Monsoon). Qasim et al. (1969) recorded a wide range of $N: P$ ratios from $0.53: 1$ to $40: 1$ during summer and monsoon periods respectively. (diciembre) con baja densidad del fitoplancton. Un comportamiento similar en la razón N:P ha sido reportado por muchos investigadores. En el estero Vellar, Rajendran (1974) obtuvo valores de 0.2:1 y 85.2:1 durante verano y el monxón, respectivamente. $R a$ madhas (1977) obtiene desde un valor mínimo de 1.5:1 en verano, a un valor alto de 32:1 en el período del monzón, en la boca del estero Vellar. En la zona entremareas del estero Vellar, Sivakumar (1982) obtiene valores de la razón $\mathrm{N}: \mathrm{P}$ de $0.02: 1$ (verano) a 170.2:1 (monzón). Qasim et al. (1969) obtiene un rango de $N: P$ de $0.53: 1$ a $50: 1$ durante el verano y ei monzón respectivamente.

Al igual que en este estudio, Sivakumar (1982) obtiene bajos valores en la razón $N: P$ durante el verano y altos valores durante el monzón. Estamos de acuerdo con él en que la influencia del agua nerítica durante el período del verano, combinada con alta población de fitoplancton, puede ser la causa de los valores bajos de la razón N:P Venugopal et al. (1981) observaron también valores bajos de la razón $\mathbf{N}$ :P en abril (inició del verano) que indican que el nitrógeno es utilizado por la población del fitoplancton del verano.

Si la razón N:P decrece por debajo del 1 , indica la proximidad del agotamiento de $\mathrm{NO}_{3}$ en el estero. (Venugopalan et al., (1981). En el presente estudio, también en marea baja, los valores mas bajos $(0.28$ y 0.75$)$ fueron registradqs durante abril y mayo. Esto está de acuerdo con lo expuesto anteriormente.

A finales del verano (junio), cuando la población del fitoplancton es alta, la razón $N$ : $P$ tiende a incrementarse como resultado del aporte de aguas dulces de las praderas vecinas. (Venugopalan et al., 1981).

En general, la razón N:P y la densidad del fitoplancton muestra una relación inversa. Valores bajos de la razón N:P ocurren durante el verano debido a la utilización del nitrógeno por la alta densidad de población del fitoplancton de verano; y durante el monzón, todo el fitoplancton del verano ha sido arrojado fuera del estero por el flujo de 
As in the present study Sivakumar (1982), noticed low values of N:P ratio during sum. mer and high values during monsoon seasons. According to him that the influence of neritic water during summer period combined with higher phytoplankton production might be responsible for lower $\mathrm{N}$ : $\mathrm{P}$ ratios. Venugopalan et al. (1981) also observed a low value of $N: P$ ratio in April (early summer) who indicated that Nitrogen was utilized by the summer phytoplancton population. The $N: P$ ratio decreased below 1 indicating a near complete exhaustion of $\mathrm{NO}_{3}$ in the estuary (Venugopalan et al., 1981). in the present study also at low tide the lowest values of 0.28 and 0.75 were recorded during April and May. This was in confirmity with the above statement.

During late summer (June) eventhough the phytoplankton population was high, the $\mathrm{N}: \mathrm{P}$ ratio was found to increase as the freshwater runoff from the adjacent paddy fields (Venugopalan et al., 1981).

In general, the N:P ratio and phytoplanklon density showed an inverse relationship. The low value of $\mathrm{N}: \mathrm{P}$ ratio was observed during summer was due to the utilization of the high density of summer phytoplankton and during monsoon all the summer phytoplankton were washed away from the estuary by freshwater inflow and so the $\mathrm{N}: \mathrm{P}$ ratio was increased. In the present study also the regression analysis between N:P ratio and phytoplankton cell counts showed a trend of negative correlation both at high

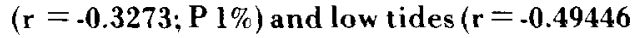
P 1\%) (Fig. 6) (Table IV).

\section{ACKNOWLEDGEMENT}

We thank the Director, Prof. K. Krishnamurthy, CAS in Marine Biology, Parangipettai for facilities provided. One of the authors (PJ) is thankful to the University Grants Commission, New Delhi for financial support. agua dulce y entonces la razón N:P se incrementa. En el presente estudio un análisis de regresión entre la razón $\mathrm{N}: \mathrm{P}$ y el número de células del fitoplancton muestra una correlación negativa tanto en marea alta $(r=$ $0.3273 ; P 1 \%)$ como en marea baja $(r=0.49446$ P 1\%) (Fig. 6) (Tabla IV).

\section{AGRADECIMIENTOS}

Agradecemos al Director Prof. K. Krishnamurty, CAS en biología marina, Parangipettai, por las facilidades otorgadas.

Uno de los autores agradece a la Gran Comisión de la Universidad de Nueva Delhi por el financiamiento.

Sergio Pou tradujo este manuscrito al español.

\section{REFERENCES}

BRUNO, F., R.D. Staker and L.L. Curtis, 1981. Seasonal variation of vitamin $B 12$ analogs, and phytoplankton in a Long Island estuary. J. Mar. Res., 39(2):335-352.

CHANDRAN, R., 1982. Hydrological studies in the gra dient zone of the Vellar estuary. Ph. D. Thesis, Annamalai University, $195 \mathrm{pp}$.

DEHADRAI, P.V. and R.M.S. Bhargava, 1972. Distribution of chlorophyll, carotenoides and phytoplankton in relation to certain environmental factors along the central west coast of India. Mar. Biol., 17:30-37.

DEVASSY, P.V. and P.M.A. Bhattathiri, 1974. Phyto plankton ecology of the Cochin backwaters. Indian J. mar. Sci., 3:46 - 50.

GAJBHIYE, S.N., M. Jiyalal Ram., R.N. Vijayalakshimi and B.N. Desai, 1981. Plankton of the Narmada estuary and adjacent creeks. Mahasagar-Bull. Natn. Inst. Oceanogr. $14(1): 23-31$.

GLEASON, H.A., 1922. On the relation between species and area. Ecology, 3:156 - 162.

GOSWAMI, S.C. and S.Y.S. Singbal, 1974. Ecology of Mardovi and Zuari estuaries, plankton community in relations to hydrographic conditions during men soon months, 1972. Indian J. mar. Sci., 31: 51 - 57 .

KRISHNAMURTHY, K., 1964. Studies in plankton and nutrients in the nearshore and estuarine waters of Porto Novo. Ph.D. Thesis, Annamalai University India. 239 pp.

KRISHNAMURTHY, K., 1967. Seasonal variations in the plankton or Porto Novo waters (India). Hydrobiol. 39: $226-238$.

KRISHNAMURTHY, K., A. Panneerselvam, and L. Kannan, 1979. Photosynthetic pigments in coastal ecosys tem. Indian J. mar. Sci., 8: 109 -111.

LARA-Lara, J. K., S. Alvarez-Borrego and L.F. Small, 1980. Variability and tidal exchange of ecological properties in a coastal lagoon. Est. coastal mar. Sci., 11: $613-637$.

PANT, A., V.K. Dhargalkar, N.B. Bhosle and A.G. Unlawale, 1980. Contribution of phytoplankton photosynthesis to a mangrove ecosystem. Mahasagar Bull. Natn. Inst. Oceanogr. 13: $225-234$. 


\section{PHYTOPLANKTON STUDIES IN VETTAR BACK WATERS}

PIELOU, E.C., 1966. The measurement of diversity in different types of biological collections. J. Theoret. Biol., 13: 131-144.

PIELOT, E.C., 1975. Ecological diversity. John Wiley and Sons. New York, $165 \mathrm{pp}$.

PURUShothamaN, A. and G.P. Bhatnager, 1976. Primary production studies in Porto Novo waters, S. India. Arch. Hydrobiol. 77: $37 \cdot 50$.

QASIM. S.Z. S. Wellershaus, P.M.A. Bhattathiri and S.A.H. Abidi, 1969. Organic production in a tropical estuary. Proc. Indian Acad. Sci., 69: 57 - 94.

QASIM. S.Z., and C.K. Gopinathan, 1969. Tidal cycle and the environmental features of Cochin backwater (a tropical estuary). Proc. India Acad. Sci., 69B: 336-348.

QASIM. S.Z., 1980. Adaptations in phytoplankton to changing conditions in tropical estuaries. MahasagarBull. Natn. Inst. Oceanogr. $13(2)$ : $117-124$.

RAJFNDRAN, A. 1974. Studies on the ecology of Vellar estuary. Chemistry and microbial regeneration of nutrients. Ph.D. Thesis, Annamalai University, India. $323 \mathrm{pp}$.

RAMADHAS, V. 1977. Studies on phytoplankton, nutrients and some trace elements in Porto Novo waters. Ph.I). Thesis, Annamalai U!niversity, $135 \mathrm{pp}$.

SANTHA VAM, R., K. Krishnamurthy and V. Sundararaj, 1975. Quantitative phytoplankton ecology. Bull. Dept. mar. Sci. University Cochin. VII, 4: 769 - 779.

SANTHANAM, R., 1976. Hidrobiological studies in Porto Vowo waters. Ecology of the phytoplankton in the different biotopes. Ph.D. Thesis, Annamalai University, $101 \mathrm{pp}$.
SANTHAKUMARI, P., 1971. Studies on phytoplankton in relation nutrients and chlorophyll at the mouth of the Vellar estuary. Ph.D. Thesis, Annamalai University, $137 \mathrm{pp}$.

SANTHA JOSEPH, P., 1982. Temporal variability of phytoplankters in Vellar estuary. Indian. J. mar. Sci., 11: $63-69$.

SIVAKUMAR, V., 1982. An environmental inventory of the tidal zone of the Vellar estuary. Ph.D. Thesis, Annamalai University, lndia, $178 \mathrm{pp}$.

SMAYDA, T.J., 1965. A quantitative analysis of the phytoplankton of the Gulf of Panama. II. On the relationship between $\mathrm{C}^{14}$ assimilation and the diatom standing crop. Inter-American Trop. Tuna. Comm. Bull. IX: $467-531$.

STRICKLAND, J.D.H. and T.R. Parsons, 1972. A practical handbook of sea water analysis. Bull. Fish. Res. Bd. Canada, No: 167, $310 \mathrm{pp}$.

SUNDARARAJ. V., 1978. Hydrobiological studies in the Vellar, Coleroon estuarine system, Ph.D. Thesis. Annamalai University, $111 \mathrm{pp}$.

THANGARAJ, G.S., V. Sivakumar., R. Chandran., R. Senthanam., B. Sri Krishnadhas and K. Ramamoorthu, 1979. An environmental inventory of Porto Novo coastal zone. Proc. Symp. Environ. Biol., 75 - 87.

VENUGOPALAN, V.K., G.S. Vijayalakshmi and A. Rajandran, 1981. Nitrate-phosphate relationship in a tropical estuarine environment. Indian J. mar. Sei., 10: $379-381$

VIJAY YLAKSHMI, G.S. and V.K. Venugopalan, 1973. Diurnal variation in the physico chemical and biological properties in Vellar estuary. Indian J. mar. Sci., 1: $125-127$. 


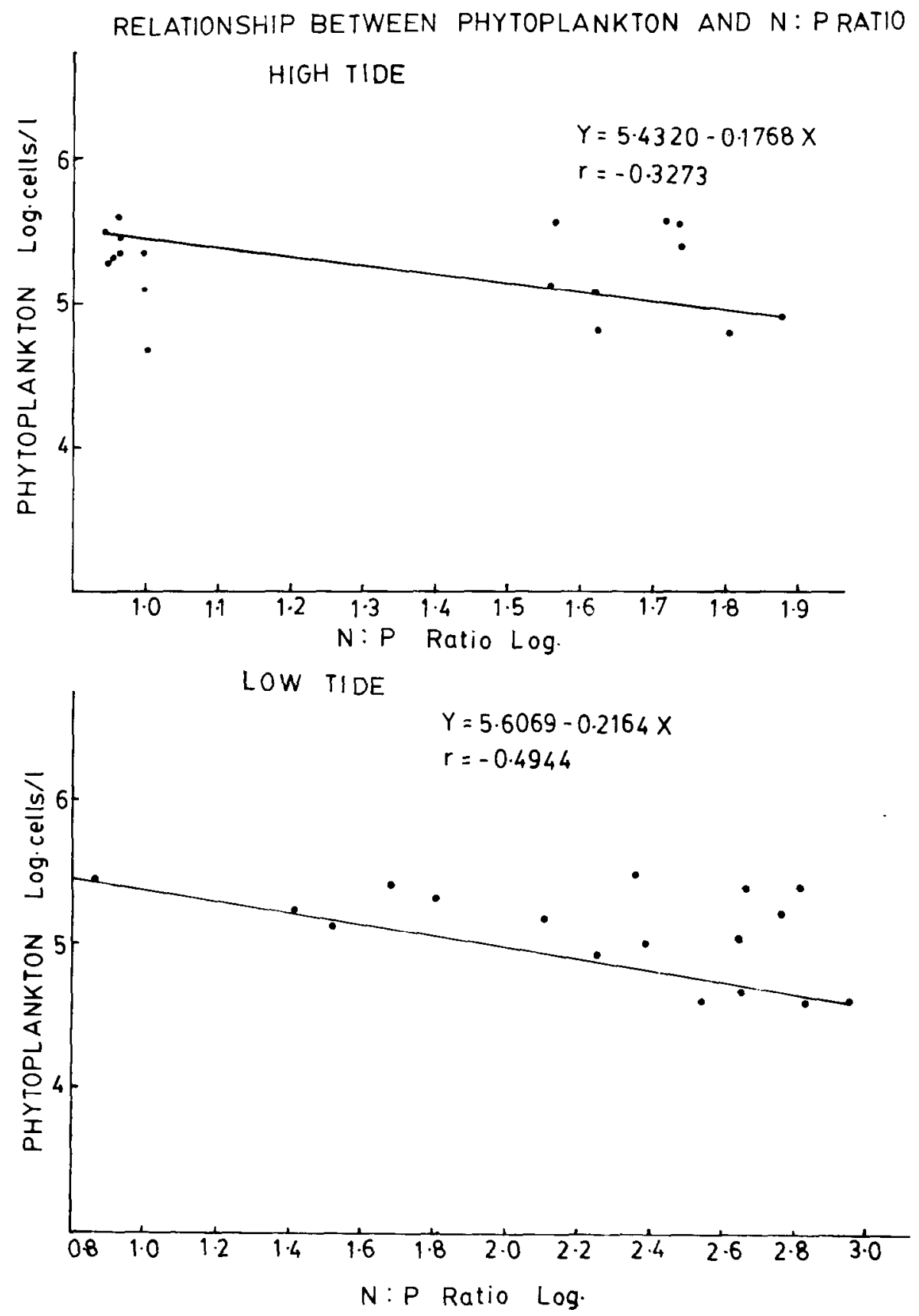

Fig. 6

Fig. 6. Relationship between phytoplankton and N:P ratio.

Relarión entre fitoplancton y razón N:P. 